\section{(6) OPEN ACCESS}

\title{
Mycoplasma pneumoniae infection presenting as stroke and meningoencephalitis with aortic and subclavian aneurysms without pulmonary involvement
}

\author{
Pournamy Sarathchandran, Abubaker Al Madani, Ayman M Alboudi, Jihad Inshasi
}

Department of Neurology, Rashid Hospital, Dubai, United Arab Emirates

\section{Correspondence to} Dr Pournamy Sarathchandran, pournamydr@gmail.com

Accepted 26 December 2017

\section{SUMMARY}

A 39-year-old Philipino man presented with acute onset fever and headache. Neurological examination was normal except for neck stiffness. There was no history of chest pain, cough or breathlessness. Cerebrospinal fluid (CSF) showed a mild increase in protein with normal sugar and lymphocytic pleocytosis. CSF PCR for herpes simplex and varicella zoster virus was negative. He developed acute right haemiplegia a week after hospitalisation. MRI showed acute infarct in the left centrum semiovale. His angiogram showed aneurysm in the left subclavian artery and aortic arch. The mycoplasma antibody test came positive with very high titres, while rest of the workup was negative. He was treated with azithromycin and his symptoms improved completely.

He was asymptomatic on follow-up after a month. His repeat immunoglobulin $\mathrm{G}$ mycoplasma antibody titre showed elevation. Mycoplasma infection is a treatable cause of meningoencephalitis and stroke secondary to vasculitis. Arterial aneurysms are known to occur with mycoplasma infection although rare.

\section{BACKGROUND}

Neurological complications due to Mycoplasma pneumonia infection are very rare being 1\%-3\% and can include meningoencephalitis, stroke, transverse myelitis, peripheral neuropathy and Guillain-Barre syndrome. ${ }^{1-3}$ They are relatively more common in children. ${ }^{3-18}$ However, isolated neurological presentation without pulmonary manifestations has not been reported.

Central nervous system (CNS) damage occurs through an autoimmune mechanism in which anti-M. pneumoniae antibodies cross-react with CNS tissue. Most cases of M. pneumoniae-associated CNS disease occur after a respiratory illness has been present for $\geq 2$ weeks, allowing for the production of $\operatorname{IgM}$ autoantibodies, which may cross-react. $^{4-6}$

We report this case of mycoplasma infection presenting with CNS manifestations in the form of stroke and meningoencephalitis, with asymptomatic arterial aneurysms. We suggest that mycoplasma infection should be considered in patients presenting with fever, aseptic meningitis and stroke even in the absence of respiratory symptoms because early detection and treatment with appropriate antibiotics offers excellent outcome.

Mycoplasma infection can be an aetiology for large vessel aneurysms as well. The presence of arterial aneurysms in a patient with fever should heighten the suspicion of mycoplasma infection.

\section{CASE PRESENTATION}

A 39-year-old Philipino man, with no previous comorbidities, drug or substance abuse or history of promiscuity presented with acute-onset, moderate-grade, intermittent fever, which was not associated with chills or rigour. There was no history of chest pain, cough or breathlessness. There were no urinary symptoms as well. He also complained of bifrontal dull aching type of headache associated with neck pain. The pain was more in the early morning hours. There was no blurring of vision or diplopia. He also complained of few episodes of vomiting. He was continuing to work in the initial few days of fever, but over 3-4 days, he became more lethargic and was unable to concentrate on the work while the headache and fever persisted. $\mathrm{He}$ consulted a local physician and was advised paracetamol and amoxicillin-clavulinic acid tablets. However, there was no relief for his symptoms. His friends who were staying with him noticed that he remained sleepy during most of the day hours and his food intake was reduced. He was able to speak coherently to them and was able to walk, although tired. They brought him to our hospital for further treatment.

At presentation he was febrile, with temperature of $100.6^{\circ} \mathrm{F}$. The pulse rate was $100 / \mathrm{min}$, blood pressure was $110 / 70 \mathrm{~mm} \mathrm{Hg}$ and respiratory rate was 18/min. There was no skin rash. Chest and cardiovascular examinations were normal. Abdominal examination did not reveal any organomegaly. On neurological examination, he appeared lethargic although responding coherently to queries. Speech was normal. Cranial nerve examination including the optic fundi was normal. Motor sensory and cerebellar examination was normal. Neck stiffness and Kernig's sign were positive.

A week after hospitalisation, he developed acute onset right-sided weakness with mild Upper Motor Neuron (UMN) type facial weakness and mild dysarthria, but there was no aphasia. 


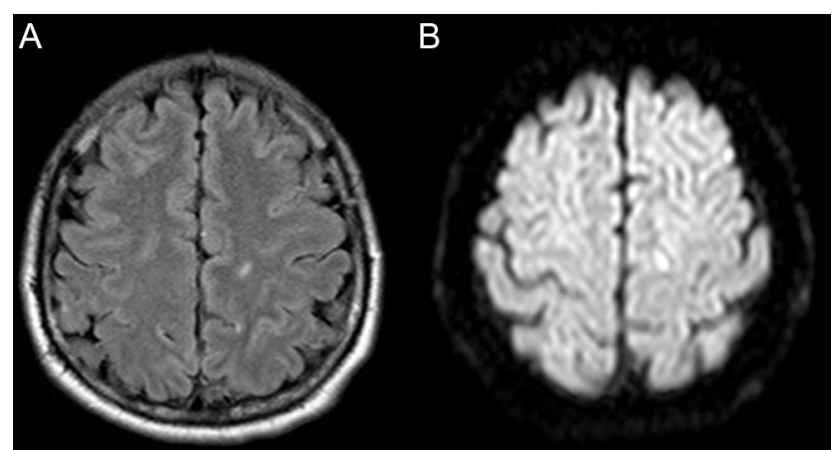

Figure 1 MRI FLAIR axial and DWI image showing acute infarct in the left centrum semi-ovale. DWI, diffusion-weighted imaging; FLAIR, fluidattenuated inversion recovery.

\section{INVESTIGATIONS}

Complete blood cell count testing revealed a haemoglobin level of $13.9 \mathrm{mg} / \mathrm{dL}$; platelet count of $450000 / \mu \mathrm{L}$; white cell count (WBC) of $10700 / \mu \mathrm{L}$, with a differential of $86 \%$ neutrophils, $12 \%$ lymphocytes and $2 \%$ monocytes. ESR was $35 \mathrm{~mm} /$ hour.

Cerebrospinal fluid (CSF) analysis showed mild increase in protein $(52 \mathrm{mg} / \mathrm{dL})$ with normal sugar $(80 \mathrm{mg} / \mathrm{dL})$ with $58 \mathrm{WBCs}$ (neutrophils 8, lymphocytes 92) and no red blood cells. CSF gram stain and culture were negative. CSF PCR for herpes simplex and varicella zoster virus was negative. Chest X-ray was normal. MRI showed acute infarct (hyperintense signal on fluid-attenuated inversion recovery and diffusion-weighted imaging images) in the left centrum semi-ovale (figure 1A, B). Electroencephalogram showed generalised slowing. His conventional angiogram showed aneurysm in the left subclavian artery and aortic arch (figure 2). Mycoplasma immunoglobulin (Ig)M antibody came positive, with a titre of $1: 100$ (positive 1:80 or more), while IgG

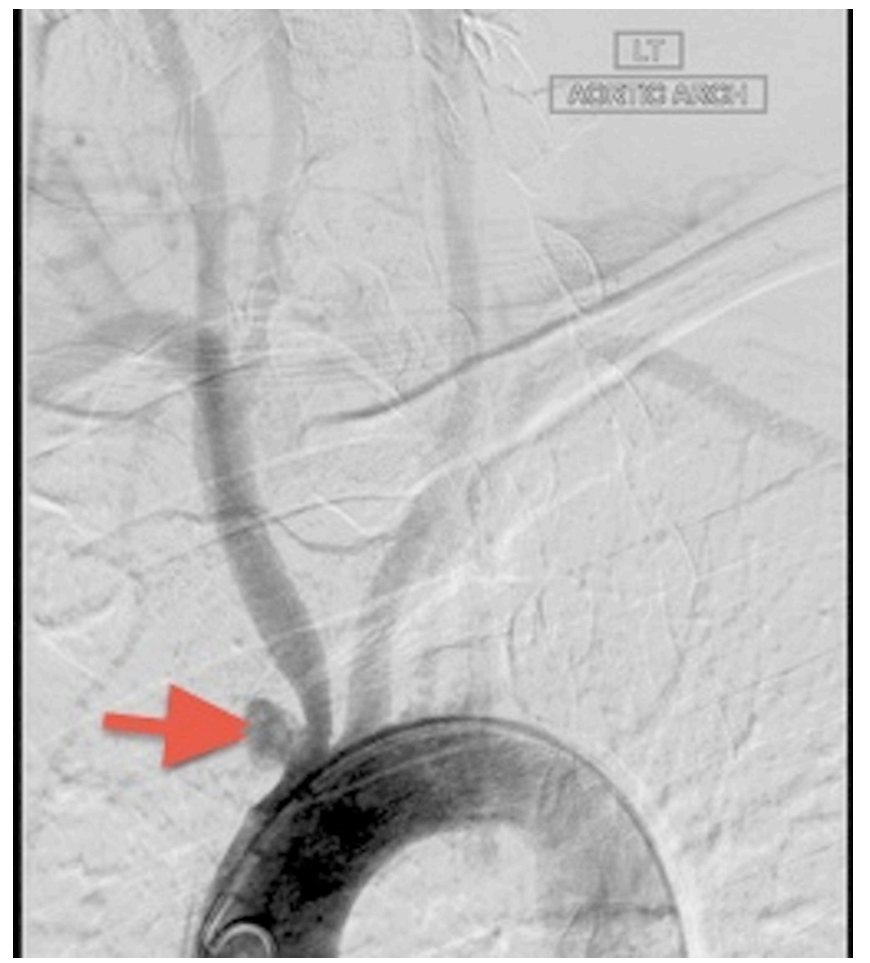

Figure 2 Aortic angiogram showing small aneurysm involving the aorta and left subclavian artery (red arrow head). titre was $1: 120$. The rest of the work up was negative. The IgG titre tested 2 weeks later showed an increase to 1:320 and was 1:80 after 3 months.

\section{DIFFERENTIAL DIAGNOSIS}

Viral meningoencephalitis, vasculitis, infective endocarditis with septic emboli and reversible cerebral vasoconstriction syndrome.

\section{TREATMENT}

He was initially treated with ceftriaxone and acyclovir with a provisional diagnosis of partially treated pyogenic/viral meningoencephalitis, which was stopped once the CSF culture PCR for herpes simplex and varicella zoster virus came negative. $\mathrm{He}$ received paracetamol for fever and headache and pantoprazole for gastric prophylaxis. He received aspirin when he developed stroke. He was started on azithromycin once the mycoplasma antibody came positive, which was continued for 5 days.

\section{OUTCOME AND FOLLOW-UP}

He became afebrile, headache subsided and sensorium improved after being initiated on azithromycin. His neurological deficits completely improved with physiotherapy. He was asymptomatic at a 1-month and 3-month follow-up.

\section{DISCUSSION}

M. pneumoniae has extrapulmonary manifestations in $25 \%$ of cases. Neurological complications of $M$. pneumoniae infection are well known and include both peripheral and CNS manifestations. ${ }^{1}$ In one study with CSF culture or PCR-proved mycoplasma, the CNS symptoms were diverse and included headache, somnolence, seizures, agitation and coma. ${ }^{2}$

Although it is rare, stroke is recognised as one of the complications, and haemiparesis had been described in the literature since 1945. However, all these manifestations were reported to be more in the paediatric population. ${ }^{3-18}$ One prospective study mentioned that the risk of ischaemic stroke was higher among people who had M. pneumoniae infection compared with controls. ${ }^{19}$ There is no clear predilection to either anterior or posterior circulations as both were described. ${ }^{9}{ }^{1114}$ The mechanism by which stroke happen is largely not understood although many has been proposed. Garcia et al proposed that M. pneumoniae infection induces a hypercoagulable state. ${ }^{18}$ This was supported by another study which showed a decrease in the circulating antithrombotic enzyme-activated protein $\mathrm{C}$ (APC), elevated plasma C4b-binding protein and lower ratio of active tissue plasminogen activator to plasminogen activator inhibitor in the stroke group with antecedent infection/inflammation within 1 week preceding brain infarction compared with the control group. ${ }^{20}$ However, thrombotic profile including APC was negative for our patient. Another mechanism suggested was the inflammatory process and vasculitis. This mechanism was supported by evidence of mycoplasma-like structure in the granulomatous angiitis of the CNS. ${ }^{21}$ In addition, both antibodies to the brain and immune complexes were described after M. pneumonia infections. ${ }^{22} 23$ This is supported by the delay of the neurological presentation in most of the patients. On the other hand, the possibility of direct invasion to the CNS was proposed based on some cases where the CSF was positive either by PCR or culture for $M$. pneumoniae. $^{210}$ Although the CSF of our patient was negative for M. pneumoniae, the patient improved with antibiotic treatment, which support the mechanism of direct invasion. However, the delay in the neurological presentation for days 
may possibly suggest autoimmunity, direct invasion or possibly both mechanisms together.

The presence of arterial aneurysms like in our patient had been previously described as a possible complication of M. pneumoniae infection. ${ }^{24}$ As with CNS manifestations, aneurysms can also be a result of direct invasion by the organism with the resultant inflammation, or because of inflammatory process caused by autoimmunity. ${ }^{25}$

\section{Learning points}

- Mycoplasma infection should be considered in patients presenting with fever, aseptic meningitis and stroke even in the absence of respiratory symptoms because early detection and treatment with appropriate antibiotics offers excellent outcome.

- Mycoplasma infection can be an aetiology for large vessel aneurysms as well.

- Presence of arterial aneurysms in a patient with fever should heighten the suspicion of mycoplasma infection.

Contributors PS: primarily responsible for the design of the work; acquisition of data, analysis and drafting the work. AMA, AARAM and Jl: assisted in the design of the work; acquisition of data, analysis, drafting the work and review of final version.

Competing interests None declared.

Patient consent Obtained.

Provenance and peer review Not commissioned; externally peer reviewed.

Open Access This is an Open Access article distributed in accordance with the Creative Commons Attribution Non Commercial (CC BY-NC 4.0) license, which permits others to distribute, remix, adapt, build upon this work non-commercially, and license their derivative works on different terms, provided the original work is properly cited and the use is non-commercial. See: http://creativecommons.org/ licenses/by-nc/4.0/

(c) BMJ Publishing Group Ltd (unless otherwise stated in the text of the article) 2018. All rights reserved. No commercial use is permitted unless otherwise expressly granted.

\section{REFERENCES}

1 Yimenicioğlu S, Yakut A, Ekici A, et al. Mycoplasma pneumoniae infection with neurologic complications. Iran J Pediatr 2014;24:647-51.

2 Socan M, Ravnik I, Bencina D, et al. Neurological symptoms in patients whose cerebrospinal fluid is culture- and/or polymerase chain reaction-positive for Mycoplasma pneumoniae. Clin Infect Dis 2001;32:e31-5.
3 Baker AB. Changes in the central nervous system associated with encephalitis complicating pneumonia. Arch Intern Med 1945;76:146-53.

4 Narita M. Pathogenesis of neurologic manifestations of Mycoplasma pneumoniae infection. Pediatr Neurol 2009;41:159-66.

5 Guleria R, Nisar N, Chawla TC, et al. Mycoplasma pneumoniae and central nervous system complications: a review. J Lab Clin Med 2005;146:55-63.

6 Yesnick L. Central nervous system complications of primary atypical pneumonia. AMA Arch Intern Med 1956;97:93-8.

7 Mulder LJ, Spierings EL. Stroke due to intravascular coagulation in Mycoplasma pneumoniae infection. Lancet 1987;2:1152-3.

8 Mulder LJ, Spierings EL. Stroke in a young adult with Mycoplasma pneumoniae infection complicated by intravascular coagulation. Neurology 1987;37:1430-1.

9 Fu M, Wong KS, Lam WW, et al. Middle cerebral artery occlusion after recent Mycoplasma pneumoniae infection. J Neuro/ Sci 1998;157:113-5.

10 Padovan CS, Pfister HW, Bense S, et al. Detection of Mycoplasma pneumoniae DNA in cerebrospinal fluid of a patient with M. pneumoniae infection- "associated" stroke. Clin Infect Dis 2001:33:e119-21.

11 Antachopoulos C, Liakopoulou T, Palamidou F, et al. Posterior cerebral artery occlusion associated with Mycoplasma pneumoniae infection. J Child Neurol 2002;17:55-7.

12 Ovetchkine $P$, Brugières $P$, Seradj A, et al. An 8-y-old boy with acute stroke and radiological signs of cerebral vasculitis after recent Mycoplasma pneumoniae infection. Scand J Infect Dis 2002;34:307-9.

13 Leonardi S, Pavone P, Rotolo N, et al. Stroke in two children with Mycoplasma pneumoniae infection. A causal or casual relationship? Pediatr Infect Dis J 2005;24:843-5.

14 Tanir G, Aydemir C, Yilmaz D, et al. Internal carotid artery occlusion associated with Mycoplasma pneumoniae infection in a child. Turk J Pediatr 2006;48:166-71.

15 Wang W, Shen KL. [Mycoplasma pneumonia associated with cerebral infarction in 3 children]. Zhonghua Er Ke Za Zhi 2009;47:946-9.

16 Lee CY, Huang YY, Huang FL, et al. Mycoplasma pneumoniae-associated cerebral infarction in a child. J Trop Pediatr 2009;55:272-5.

$17 \mathrm{Kim} \mathrm{GH}$, Seo WH, Je BK, et al. Mycoplasma pneumoniae associated stroke in a 3-yearold girl. Korean J Pediatr 2013;56:411-5.

18 Garcia AV, Fingeret AL, Thirumoorthi AS, et al. Severe Mycoplasma pneumoniae infection requiring extracorporeal membrane oxygenation with concomitant ischemic stroke in a child. Pediatr Pulmonol 2013;48:98-101.

19 Chiang CH, Huang CC, Chan WL, et al. Association between Mycoplasma pneumonia and increased risk of ischemic stroke: a nationwide study. Stroke 2011;42:2940-3.

20 Macko RF, Ameriso SF, Gruber A, et al. Impairments of the protein C system and fibrinolysis in infection-associated stroke. Stroke 1996;27:2005-11.

21 Arthur G, Margolis G. Mycoplasma-like structures in granulomatous angiitis of the central nervous system. Case reports with light and electron microscopic studies. Arch Pathol Lab Med 1977; 101:382-7.

22 Biberfeld G. Antibodies to brain and other tissues in cases of Mycoplasma pneumoniae infection. Clin Exp Immunol 1971;8:319-33.

23 Biberfeld G, Norberg R. Circulating immune complexes in Mycoplasma pneumoniae infection. J Immunol 1974;112:413-5.

24 Roggério A, Sambiase NV, Palomino SA, et al. Correlation of bacterial coinfection versus matrix metalloproteinase 9 and tissue inhibitor of metalloproteinase 1 expression in aortic aneurysm and atherosclerosis. Ann Vasc Surg 2013;27:964-71.

25 Lindholt JS, Shi GP. Chronic inflammation, immune response, and infection in abdominal aortic aneurysms. Eur J Vasc Endovasc Surg 2006;31:453-63.

Copyright 2017 BMJ Publishing Group. All rights reserved. For permission to reuse any of this content visit http://group.bmj.com/group/rights-licensing/permissions.

BMJ Case Report Fellows may re-use this article for personal use and teaching without any further permission.

Become a Fellow of BMJ Case Reports today and you can:

- Submit as many cases as you like

- Enjoy fast sympathetic peer review and rapid publication of accepted articles

- Access all the published articles

- Re-use any of the published material for personal use and teaching without further permission

For information on Institutional Fellowships contact consortiasales@bmjgroup.com

Visit casereports.bmj.com for more articles like this and to become a Fellow 